\title{
NANOTECHNOLOGY AS A NEW PERSPECTIVE FOR MODERNIZATION OF TECHNICAL SUBJECTS CURRICULA AT PRIMARY AND SECONDARY SCHOOLS
}

\author{
Zuzana TKÁČOV $\boldsymbol{A}^{*}$, Univerzita Konštantína Filozofa v Nitre, Slovenská \\ republika
}

Přijato: 15. 1. 2017 / Akceptováno: 9. 3. 2017

Typ článku: Teoretická studie

DOI: $10.5507 /$ jtie.2017.007

Abstract: Nanotechnologies are currently considered to be promising and dynamically advancing scientific and technical trend, offering opportunities to improve the properties of traditional materials, or create entirely new ones. The paper will focus on the presentation of opportunities to link the issues of nanotechnology to existing curricula of technical subjects at primary and secondary schools in Slovakia with allocating of the appropriate subject areas and themes that can be upgraded by incorporating nanotechnology issues. We also provide the analysis of the materials, methodology and staff requirements for the implementation of nanotechnology into technical subjects teaching process.

Key words: curriculum, technology education, engineering, nanoeducation, nanotechnology.

\section{NANOTECHNOLÓGIE AKO NOVÁ PERSPEKTÍVA PRE MODERNIZÁCIU KURIKULA TECHNICKÝCH PREDMETOV NA ZÁKLADNÝCH A STREDNÝCH ŠKOLÁCH}

Abstrakt: Nanotechnológie sú $v$ súčasnosti považované za perspektivny a dynamicky napredujúci vedecký a technický smer, ktorý ponúka možnosti, ako zdokonalit' vlastnosti tradičných materiálov alebo vytvorit' úplne nové. $V$ príspevku sa zameriame na predstavenie možností prepojenia problematiky nanotechnológii na existujúce kurikulum technických predmetov základných a stredných škôl na Slovensku s vyčlenením vhodných tematických oblastí a tém, ktoré je možné začlenením nanotechnológii modernizovat'. Taktiež analyzujeme požiadavky na materiálne, metodické a personálne zabezpečenie implementácie nanotechnológii do vyučovacieho procesu technických predmetov.

Klúčové slová: kurikulum, technické vzdelávanie, technika, nanovzdelávanie, nanotechnológie.

*Autor pro korespondenci: zuzana.tkacova@ukf.sk 


\section{1 Úvod}

Nanotechnológie predstavujú technológie a postupy, ktoré prostredníctvom riadenej manipulácie s atómami alebo molekulami vytvárajú nanomateriály, nanozariadenia alebo nanostroje s výnimočnými vlastnost’ami vyplývajúcimi z vlastností hmoty v nanorozmeroch. V súčasnosti sú považované za perspektívny a dynamicky napredujúci vedecký a technický smer, ktorý ponúka možnosti, ako zdokonalit' vlastnosti tradičných materiálov alebo vytvorit' úplne nové. V každodennom živote je možné sa stretnút' s mnohými komerčnými výrobkami a zariadeniami, ktoré využívajú nanomateriály alebo nanotechnológie. $\mathrm{Z}$ pohl'adu didaktiky predstavujú nanotechnológie silne interdisciplinárnu oblast', ktorá prepája poznatky prírodných a technických vied a ponúkajú učitel'om možnost' obohatit' výučbu týchto predmetov o zaujímavé a predovšetkým aktuálne vedecké a technické poznatky. Preto sa od začiatku 21. storočia začali objavovat' $v$ rôznych krajinách (EÚ, USA, Japonsko, Austrália a i.) projekty a iniciatívy sledujúce prepojenie nanotechnológií $\mathrm{s}$ prírodovednými a technickými predmetmi $\mathrm{v}$ podmienkach základných a stredných škôl, ktoré postupne viedli k vytvoreniu odporúčaného nanotechnologického kurikula (obr. 1).
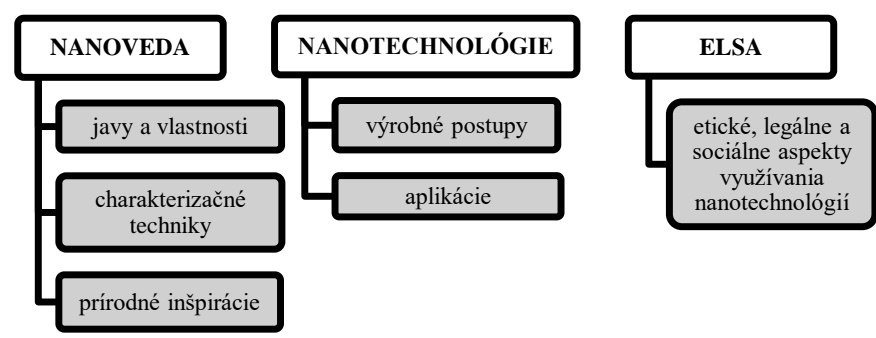

\section{Obr. č. 1: Odporúčané nanokurikulum pre druhý stupeň ZŠ a SŠ (podl'a European SchoolNet, 2010)}

Základné východiská a odporúčania pre systematickú komunikačnú stratégiu venovanú nanotechnológiám $\mathrm{v}$ spoločnosti (kam spadá aj nanoedukácia na školách) môžeme nájst' v správe z Bruselského workshopu (Bonazzi \& Palumbo, 2007), na ktorý nadviazali európske projekty, napr. Time for Nano (http://www.timefornano.eu/), NANOYOU (Nanotechnology for Youth, http://nanoyou.eu/), Nanochannels (http://www.nanochannelsfp7.eu), Seeing Nano (http://www.seeingnano.eu/), NanoWOW (http://www.crann.tcd.ie/Education-Outreach/NanoWOW.aspx), Nano in My Life (http://www.crann.tcd.ie/Education-Outreach/School-s-Programme/Nano-inMy-Life.aspx) a d'alšie, využivajúce predošlé skúsenosti a didaktické prístupy navrhnuté a overené $v$ nanocentrách v USA. Napriek značnej rozmanitosti edukačných aktivít a nástrojov zo spomínaných európskych projektov, všetky z nich pokrývajú jednotlivé oblasti a témy odporúčaného nanokurikula (podl'a obr. 1).

Samotná implementácia nanotechnológií do vyučovacieho procesu závisí na špecifikách školy. Ked’že európske krajiny neponúkajú nanotechnológie ako samostatný 
predmet vo svojich oficiálnych vzdelávacích programoch, témy z nanokurikula sa zvyčajne presúvajú do príbuzných predmetov ako je fyzika alebo chémia (Kaya \& Karatas, 2016), (Tkáčová \& Lavický, 2014), (Stevens, Sutherland, \& Krajcik, 2009). Technický a technologický charakter problematiky nanotechnológií však prirodzene otvára priestor na prepojenie aj na kurikulum technických predmetov v podmienkach ZŠ a SŠ, pričom ako inšpirácia môže poslúžit kurikulum projektu NanoWOW a projektu Nano in My Life, určené pre druhý stupeň základnej školy.

\section{Metódy}

Pri spracovaní tejto štúdie sme vychádzali z obsahovej analýzy národných a medzinárodných kurikulárnych dokumentov a výsledkov výskumných projektov zameraných na problematiku nanoedukácie na základných a stredných školách, najmä európskych projektov NANOYOU, Seeing Nano, NanoWOW, pri ktorých sme sa zamerali na selekciu dostupných materiálov vhodných jednak pre druhý stupeň základných škôl (v prepojení na tematické celky predmetu Technika), jednak pre stredné školy (v prepojení na odborné technické predmety).

\section{Prepojenie výučby nanotechnológií na kurikulum technických predmetov}

Na Slovensku vzdelávací štandard predmetu Technika na základnej škole (Štátny pedagogický ústav, 2014) v tematickom okruhu Technika zahŕña tematické celky Človek a technika, Technické materiály a pracovné postupy ich spracovania a Technická elektronika, obsah ktorých je možné modernizovat' zavedením niektorých špecifických tém z nanokurikula.

V tematickom celku Človek a technika je riešený vzt’ah medzi technickým, prírodným

a spoločenským prostredím, ako aj otázky ochrany prírody a pozitívnych/negatívnych vplyvov techniky, čo je v nanokurikulu zastrešené problematikou ELSA (etické, legálne a sociálne aspekty využívania nanotechnológií). Využit' môžeme rôzne vol'ne dostupné videá na internete (napr. oficiálne video NanoInLife, http://goo.gl/DSKZ4n) alebo viacero metodík $\mathrm{z}$ projektu NANOYOU $\mathrm{k}$ rolovým hrám (http://goo.gl/35Ctti) zameraným na formovanie postojov $\mathrm{k}$ novým technológiám $\mathrm{v}$ spoločnosti a zvažovanie ich benefitov a prípadných rizík.

V tematickom celku Technické materiály a pracovné postupy ich spracovania je vhodné zaradit' do výučby ukážky niektorých nových typov inteligentných (SMART) materiálov (napr. magnetické kvapaliny, zliatiny s tvarovou pamätou alebo elektricky vodivé polyméry), ktoré je možné zakúpit' prostredníctvom internetu jednak ako demonštračné pomôcky, jednak na tvorivé aktivity žiakov do ich vlastných projektov. Pri technických materiáloch sa spomínajú aj možnosti povrchových úprav, čo predstavuje priestor na ukážku alebo priame žiacke experimenty s nanomateriálmi v podobe rôznych druhov komerčne dostupných nanolakov, napr. odolných voči vode, špine, oderu, ohňu alebo meniacich farbu.

Tematický celok Technická elektronika ponúka priestor na začlenenie tém venovaných nanoelektronike s ohl’adom na perspektívy vývoja nových elektronických zariadení (zobrazovacie jednotky, procesory, pamätové zariadenia, inteligentné nositel'né elektronické zariadenia, nové druhy solárnych článkov, tlačená elektronika a pod.). 
Z pohl'adu odborného technického a technologického vzdelávania na stredných školách sú možnosti integrácie nanokurikula do odborných predmetov bohatšie, ked’že nanotechnológie nachádzajú v súčasnosti uplatnenie v mnohých oblastiach. Prirodzený priestor pre túto problematiku sa otvára $\mathrm{v}$ predmetoch venovaných materiálom a technológiám alebo fyzikálnym základom technických disciplín v elektrotechnických, strojárskych, energetických alebo chemických odboroch. V optimálnom prípade je možné nanokurikulum rozdělit postupne do viacerých na seba nadväzujúcich predmetov tak, aby si študent postupne rozširoval vedomosti a prepájal ich s obsahom základných predmetov. Iný prístup predstavuje vytvorenie samostatného tematického celku v kurikulu vhodného odborného predmetu. Školy môžu zvážit' aj ponúknutie samostatného volitel’ného predmetu s kompletným nanokurikulom v rámci svojich školských vzdelávacích programov, čo je vhodné realizovat' napr. pri školách elektrotechnického zamerania.

\section{Požiadavky na materiálne, metodické a personálne zabezpečenie implementácie nanotechnológií do vyučovacieho procesu technických predmetov}

Na podporu efektívnej implementácie nanotechnológií do vyučovania je nevyhnutné zabezpečit' vhodnú materiálnu a metodickú podporu vyučovacieho procesu, ako aj odbornú prípravu učitel'ov.

Napriek prvotnému dojmu, že výučba nanotechnológií je v podmienkach bežnej triedy len tažko realizovatel'ná, na trhu sučebnými pomôckami sú v súčasnosti $\mathrm{k}$ dispozícii ako jednotlivé pomôcky pre demonštračné, či experimentálne aktivity s konkrétnymi nanomateriálmi, tak aj komplexné riešenia formou tzv. nanokitov, edukačných sád pokrývajúcich systematicky celú oblast' nanokurikula, napr. NanoSchoolBox (http://www.nanoschoolbox.de/).

Metodickú podporu môžu učitelia čerpat' z materiálov, ktoré vznikli ako súčast' riešenia medzinárodných nanoedukačných projektov, ktoré boli spracované aj do podoby rozsiahleho kompendia pre učitel'ov (Filipponi \& Sutherland, 2012); napriek tomu, že väčšina týchto materiálov je dostupná $\mathrm{v}$ anglickom jazyku, niektoré projekty priniesli výstupy dostupné aj v slovenskom alebo českom jazyku (napr. projekty NANOYOU a Seeing Nano). Vd'aka rozmanitosti spracovaných materiálov získajú učitelia inšpirácie, ako vyučovat' problematiku nanovedy a nanotechnológií pútavou a atraktívnou formou s využitím hier, pokusov, či multimédií aj bez nárokov na špeciálne materiálne a finančne náročné vybavenie.

$\mathrm{V}$ posledných rokoch sa začalo aj s odbornou prípravou učitel'ov na vyučovanie nanotechnológií. Univerzitné a výskumné pracoviská na Slovensku ponúkajú tematické workshopy a prednášky pre učitel'ov spojené $\mathrm{s}$ exkurziami do svojich laboratórí́. Komplexný 60-hodinový akreditovaný program inovačného vzdelávania Základy nanovedy a nanotechnológií (Metodicko-pedagogické centrum, n.d.) ponúka pre učitel'ov prírodovedných a technických predmetov na ZŠ a SŠ Metodicko-pedagogické centrum. Aj vd'aka tejto iniciatíve sa postupne na Slovensku rozrastá siet' základných škôl, gymnázií aj SOŠ, ktoré zaradili nanotechnológie do kurikula svojich predmetov. 


\section{Diskusia}

Prezentované možnosti modernizácie kurikula technických predmetov včleňovaním problematiky nanotechnológií rešpektujú súčasné požiadavky na technické vzdelávanie rozšírením tried techniky a technológií týkajúcich sa rozsiahlych skupín užívatel'ov, prirodzene reflektujúc záujmy dnešných žiakov ako užívatel'ov týchto technológií a so zretel'om aj na širšie uplatňovanie postupov hodnotenia techniky a následkov jej využívania v spoločnosti (Serafín et al., 2016).

Nanotechnológie môžu pre nezainteresovaných predstavovat' vel'mi abstraktnú a odborne i technicky náročnú problematiku, ktorou by nemali byt' žiaci základných škôl zat'ažovaní. Tento prístup môže komplikovat' implementáciu do kurikula na národnej alebo školskej úrovni. Avšak bohaté skúsenosti zo zahraničia poukazujú na pozitívne ohlasy a výsledky zo školskej praxe a aktuálne sa pracuje na nových edukačných projektoch, ktoré majú sprístupnit' nanoproblematiku veku primeraným spôsobom det'om už vo veku 5-13 rokov.

Pri zavádzaní nanotechnológií do vyučovania je potrebná intenzívnejšia spolupráca s vysokými školami a výskumnými centrami, ktoré by mali aktívne participovat' pri príprave učitel'ov a učebných materiálov, realizácii odborných exkurzií a podpore žiakov pri realizácii ich vlastných výskumných a technických projektov. Priame prepojenie na regionálne výskumné a inovačné centrá zvyšuje atraktivitu problematiky nanotechnológií, čo ovplyvňuje motiváciu žiakov a ich d'alšie smerovanie k štúdiu technických disciplín a odborov.

\section{Záver}

Prebiehajúca reforma vzdelávania v základných a stredných školách umožňuje školám a učitel'om upravovat' a prispôsobovat' vzdelávací obsah aj formy jeho sprístupňovania. Dostupné materiály, ale aj skúsenosti z realizovaných medzinárodných nanoedukačných projektov poskytujú konkrétne námety a inšpirácie, ako včlenit' najnovšie poznatky vedy a techniky do vyučovania nenásilnou a pútavou formou. V súčasnej situácii pri klesajúcom záujme o technické štúdium tak môžu nanotechnológie ponúknut' perspektívny prístup k modernizácii ponúkaného technického kurikula na ZŠ a ŠS.

\section{Literatúra}

Bonazzi, M., \& Palumbo, J. (Eds.) (2007). Communication Outreach in Nanotechnology: from recommendations to action [Report from the Workshop, Brussels, 24-25 October, 2007]. European Commission. Dostupné z:

http://cordis.europa.eu/pub/nanotechnology/docs/nanooutreach action final mar 08.doc European SchoolNet (2010). NANOYOU in School: Communicating NANOtechnology to European YOUTH - Lesson modules. Brusel: European SchoolNet. Dostupné z: http://nanoyou.eu/attachments/613_Nanoyou\%20teacher\%20guide.pdf

Filipponi, L., \& Sutherland, D. (2012). Nanotechnologies: Principles, Applications, Implications and Hands-on Activities. A kompendium for educators. Luxembourg: Publications Office of the European Union.

Kaza, N., \& Karatas, H. (2016). Nanotechnology in the Curriculum: a Review of the Literature. Eurasian Journal of Physics \& Chemistry Education, 8(2), 49-58. doi: 10.12973/ejpce.2016.00005a 
Metodicko-pedagogické centrum (n.d.). Program kontinuálneho vzdelávania: Základy nanovedy a nanotechnológií. Bratislava: Metodicko-pedagogické centrum. Dostupné z: http://www.mpc-edu.sk/library/files/zakl_nanovedy_a_nanotechnologii.pdf

Serafin, Č. et al. (2016). Proměna kurikula technické výchovy v České a Slovenské republice po roce 1989. Olomouc: Univerzita Palackého v Olomouci.

Stevens, S. Y., Sutherland, L. M., \& Krajcik, J. S. (2009). The big ideas of nanoscale science \& engineering: a guidebook for secondary teachers. Arlington, Virginia: NSTA Press.

Štátny pedagogický ústav (2014). Vzdelávaci štandard predmetu Technika - nižšie stredné vzdelávanie. Bratislava: Štátny pedagogický ústav. Dostupné z:

http://www.statpedu.sk/sites/default/files/dokumenty/inovovany-statny-vzdelavaciprogram/technika nsv 2014.pdf

Tkáčová, Z., \& Lavický, T. (2014). Základy nanovedy a nanotechnológii pre učitelov. Bratislava: Metodicko-pedagogické centrum v Bratislave.

Prehl'ad odkazov na nanoedukačné projekty a materiály:

Projekt Time for Nano (http://www.timefornano.eu/)

Projekt NANOYOU (Nanotechnology for Youth, http://nanoyou.eu/)

Projekt Nanochannels (http://www.nanochannelsfp7.eu)

Projekt Seeing Nano (http://www.seeingnano.eu/)

Projekt NanoWOW (http://www.crann.tcd.ie/Education-Outreach/NanoWOW.aspx)

Projekt Nano in My Life (http://www.crann.tcd.ie/Education-Outreach/School-s-

Programme/Nano-in-My-Life.aspx)

Video NanoInLife, http://goo.gl/DSKZ4n)

Metodiky z projektu NANOYOU k rolovým hrám (http://goo.gl/35Ctti)

Edukačná sada NanoSchoolBox (http://www.nanoschoolbox.de/) 